\title{
Práticas de leitura na contemporaneidade: experiências em bibliotecas na cidade do rio de janeiro
}

\author{
Prácticas de lectura en la contemporaneidad: \\ experiencias en bibliotecas de la ciudad de Rio de Janeiro
}

Reading practices in contemporaneity: libraries' experiences in the city of Rio de Janeiro

\author{
Marisa Schincariol de Mello'
}

\section{Palavras chave: \\ Rio de Janeiro \\ Bibliotecas \\ Práticas de leitura \\ Leitura do mundo \\ Experiências}

\section{Resumo:}

O presente artigo tem por objetivo principal apresentar uma investigação acerca das múltiplas práticas de leitura em bibliotecas localizadas na cidade do Rio de Janeiro. Para a realização deste estudo, buscamos delimitar o universo de frequentadores, suas práticas de leitura na biblioteca, os mediadores entre os textos, sons, imagens e a leitura, bem como as relações entre os espaços das bibliotecas e os territórios onde estão inseridos. Investiga-se ainda qual a importância e a função da leitura para os que a praticam, nos níveis objetivo, subjetivo, simbólico e imaginário. Através de entrevistas e da observação participante, procuramos trazer à tona a relação dos usuários com os livros, outros conteúdos, mídias e suportes. Cada vez mais, observamos práticas que combinam leitura, oralidade e escrita em um cenário transmidiático. Com os resultados, procura-se também contribuir com informações sobre a experiência dos usuários para a formulação e avaliação das políticas públicas de leitura e aquelas voltadas para as bibliotecas. 


\section{Resumen:}

El presente artículo tiene por objetivo principal presentar una investigación acerca de las múltiples prácticas de lectura en bibliotecas ubicadas en la ciudad de Rio de Janeiro. Para la realización de este estudio, buscamos delimitar el universo de sus frecuentadores, sus prácticas en la biblioteca, los mediadores entre los textos, sonidos, imágenes y la lectura, además de las relaciones entre los espacios de las bibliotecas y los territorios que las abarcan. Investigamos además cual es la importancia y función de la lectura para sus practicantes, en los niveles objetivo, subjetivo, simbólico e imaginario. A través de entrevistas y de la observación participante, buscamos recuperar la relación del público con los libros y otras formas de lectura del mundo, a través de otros suportes, como el audiovisual, la música, etc. Cada vez más, observamos prácticas que combinan lectura, oralidad y escrita en un escenario transmediático. A partir de los resultados se pretende contribuir para la formulación y evaluación de las políticas públicas de lectura y bibliotecas.
Palabras clave:

Rio de Janeiro

Bibliotecas

Prácticas de lectura

Lectura de mundo

Experiencias

\section{Keywords:}

Rio de Janeiro

Libraries

Reading practices

Reading the world

Experiences

\section{Abstract:}

The major purpose of this article is to present a research on the multiple reading practices in libraries in the city of Rio de Janeiro. We attempted, firstly, to define the universe of its users, their reading practices at the library, the mediators between the texts, sounds, images and reading, as well as the relationships between the libraries' venues and the territory in which they are set in. It is also analyzed what is the importance and function of the reading for those who practice it, in objective, subjective, symbolic and imaginary levels. Through interviews and participant observation, we tried to highlight the users' relationship with books, other contents, medias and formats. We increasingly observe practices that combine reading, orality and writing in a transmedia scenery. Thus, we hope to contribute with information on the experience of the users for the formulation and evaluation of public reading and libraries' policies. 


\section{Práticas de leitura na contemporaneidade: experiências em bibliotecas na cidade do Rio de Janeiro}

O Segundo Chartier (1998), a história das "possibilidades de ler" não trata apenas de uma habilidade, mas da ativa elaboração de significados dentro de um sistema de comunicação. A leitura não é um ato natural ou passivo de sujeição ao texto, mas se configura como um processo cognitivo, semiológico, culturalmente demarcado, social e histórico de caráter complexo e interativo entre a mensagem e o conhecimento; uma prática de reapropriação e de recriação do mundo através da interpretação. O comportamento leitor determina a força motivadora das práticas de leitura, que é influenciada pelos contextos socioeconômicos e pelas competências leitoras, compostas por diversas formas de combinação possíveis entre leitura, oralidade e escrita (METODOLOGIA, 2015; CHARTIER, 2011; ZILBERMAN, s.d.).

Nas páginas que se seguem, procuramos observar, auscultar e refletir sobre as práticas de leitura e as relações entre a cultura e as territorialidades, especialmente a partir das bibliotecas. A metodologia adotada buscou aproximar-se do tema por vias diversas, desde o levantamento das políticas e dados gerais existentes sobre leitura, com análise de bibliografia pertinente ao tema, até o estudo de caso comparativo entre duas bibliotecas, através da observação participante e da realização de entrevistas com usuários, funcionários e gestores.

\section{Mediações da leitura}

Ao buscar delimitar o sujeito oculto que lê, nos deparamos primeiramente com os meios de comunicação, quer sejam escritos, como livros, jornais e revistas; audiovisuais, como a televisão e o cinema; sonoros, como o rádio e o telefone; e hipermídia, como a internet. Seguindo a proposição de Jesús Martín-Barbero (2009) em tentar ir além dos meios, buscamos principalmente identificar as mediações, aqui entendidas como o contexto onde a prática da leitura acontece.

A prática da leitura que ocorre em casa, em geral a partir das famílias, seria muito difícil de delinear. Dessa maneira, para traçar um quadro mais geral da leitura no Brasil, utilizamos as pesquisas de indicadores. O Instituto Pró-Livro promoveu quatro edições, nos anos de 2000 , 2007, 2011 e 2015, de uma pesquisa intitulada Retratos da Leitura no Brasil, sendo o primeiro levantamento mais abrangente realizado sobre o assunto no país."

A pesquisa Retratos da Leitura no Brasil de 2016 aponta os principais locais onde as pessoas leem: em casa $(81 \%)$, na sala de aula $(25 \%)$ e na biblioteca (29\%) - sendo que $14 \%$ leem em bibliotecas escolares ou da faculdade, enquanto apenas $8 \%$ em bibliotecas públicas. Há ainda outras modalidades de leitura que são cada vez mais frequentes, como a leitura em trânsito, que geralmente ocorre no trajeto casa-trabalho-casa $(11 \%$ declararam ler no transporte público ou no avião)."'I Como mapear esses contextos?

Em relação à quantidade de livros lidos por ano, segundo a Pesquisa, entre todos os entrevistados, a média era de 1,8 em 2000 (26 milhões de leitores); 4,7 em 2007 (66,5 milhões de leitores); 4,0 em 2011 (71,9 milhões de leitores); e 4,96 em 2015. IV Os resultados gerais da pesquisa em 2011 revelaram uma enorme concentração: $66 \%$ dos livros estão nas mãos de apenas $20 \%$ da população (FAILLA, 2012). 
A última edição da pesquisa classificou como não leitores aqueles que não leram um livro, inteiro ou em parte, nos três meses anteriores à pesquisa e eles representaram um total de $44 \%$ da amostra. Desses, apenas $9 \%$ dos entrevistados disseram ter dificuldade para a leitura, o que revela também a falta de estímulo à prática. As razões alegadas por muitos entrevistados dessa categoria foram falta de tempo (32\%), desinteresse $(28 \%)$, falta de paciência $(13 \%)$ e preferência por outras atividades (10\%). Entre todos os entrevistados, são considerados não alfabetizados um total de $8 \%$ da amostra, enquanto $21 \%$ têm até a $4^{a}$ série, faixa em que as práticas de leitura ainda não estão consolidadas. A maior parcela de não leitores está entre os adultos idosos (representando $73 \%$ dos entrevistados nessa categoria) e mais pobres. ${ }^{\vee}$ A pesquisa demonstrou que a porcentagem de leitores aumenta significativamente nas categorias com maior renda familiar, enquanto a porcentagem de não leitores diminui. Isso leva à conclusão de que o poder aquisitivo é significativo para a constituição de leitores assíduos. ${ }^{\mathrm{V}}$

A classificação do leitor como aquele que leu um livro inteiro ou em partes nos últimos três meses, no entanto, é insuficiente para dar conta das práticas de leitura, que estão cada vez mais diversificadas e fragmentadas em modalidades, linguagens, suportes e janelas. A partir da pesquisa realizada e dos debates recentes sobre as transformações no campo da leitura (METODOLOGIA, 2015), identificamos uma faixa grande intermediária entre os/as leitores/as assíduos/as e os analfabetos funcionais, que não consegue reconhecer determinadas práticas que as pesquisas quantitativas não conseguem alcançar. É muito difícil determinar onde começa e onde termina uma experiência de leitura. Aqui, dessa maneira, partimos de um conceito am- pliado de leitura, considerando, a partir dos preceitos de Paulo Freire, que a leitura do mundo precede a leitura da palavra, valorizando as práticas que contribuem para dar sentido à vida daqueles que as praticam e não apenas as que se referem à leitura de textos e livros.

Um dos dados que chama atenção na pesquisa Retratos da Leitura de 2015 é que, se somados, $50 \%$ dos cerca de 5 mil entrevistados indicaram o empréstimo, com parentes, conhecidos ou em bibliotecas, como o principal meio de acesso ao livro. Portanto, meios não mercantis de acesso ao livro. VII A significativa incidência da obtenção de livros por meios não comerciais revela uma modalidade de transação em que as editoras não penetram, mas que são de importância fundamental para a leitura no país. Os circuitos de empréstimos tanto pessoais quanto de bibliotecas, bem como a reciclagem de livros usados no mercado secundário, constituem áreas de pesquisa que merecem ser desenvolvidas (FAILLA, 2012).

Já no que se refere às bibliotecas, $66 \%$ dos entrevistados não as frequentam. Apenas $20 \%$ as frequentam com alguma regularidade, dos quais $47 \%$ são estudantes. VIII A população que não frequenta as bibliotecas públicas tem como principal argumento a falta de tempo, a distância e a falta de interesse pela leitura e por frequentar esse tipo de equipamento. Ao mesmo tempo, são os equipamentos culturais mais existentes nos municípios brasileiros. Isso abre uma possibilidade para os espaços das bibliotecas se reinventarem, ampliarem suas funções e suportes de leitura para encantarem um número maior de usuários. O que na prática não acontece. $O$ primeiro Censo Nacional de Bibliotecas Públicas Municipais, realizado em 2009 e publicado em 2010, apontou um número insuficiente de bibliotecas por habitante, 
além da precariedade da infraestrutura das existentes; acervos limitados e desatualizados; falta de acesso ao universo digital; baixa frequência; limitação do uso da biblioteca para obrigações escolares; entre outras questões (MARQUES NETO, 2015, p. 131).

Além dessas pesquisas quantitativas e financiadas pela indústria do livro, é importante realizar análises que levem em conta o contexto complexo e dinâmico em que as práticas de leitura acontecem na contemporaneidade; 0 que motivou essa pesquisa em bibliotecas. A leitura não é um ato passivo de sujeição aos textos e conteúdos, ou uma prática homogênea, desde a quantidade e frequência, passando pelos suportes, gêneros literários e o tipo de experiência que proporciona. Ou seja, até chegar ao receptor, a mensagem passa por mediações diversas, conforme a organização da sociedade. O uso ou a recepção dos produtos também varia conforme o contexto em que se insere. Os mesmos conteúdos são objeto de diferentes usos e investimentos sociais, às vezes de caráter oposto e contraditório (LAHIRE, 2004). As razões alegadas pelos que leem também são variadas. A pesquisa qualitativa acrescenta dados, questiona princípios, metodologias, e oferece a oportunidade de enriquecer os dados com a experiência e os referentes dos envolvidos nesse processo.

A escola constitui-se em um espaço fundamental de aprendizagem, valorização e consolidação da leitura, cooperando com o processo de legitimação da literatura e da escrita. Sua história ao longo do século XX compreende diferentes filosofias educacionais, concepções relativas aos processos de ensino e modos de organização do aparelho pedagógico. Nos últimos vinte anos, o tema do fomento à leitura na escola vem sendo estudado sistematicamente, e o resultado aponta para um fracasso relativo às políticas de inserção da prática no ambiente escolar.

Regina Zilberman (s.d.) chama a atenção para o fato de que a leitura como prática, nas suas várias acepções, em nossa sociedade ainda é hegemonicamente um "produto da escola e critério para ingresso e participação do indivíduo na sociedade" e responsável "por distinguir o homem alfabetizado e culto do analfabeto e ignorante". Ao mesmo tempo, afastou o homem comum da cultura oral. "Nesse sentido, cooperou para acentuar a clivagem social, sem, contudo, revelar a natureza de sua ação, pois colocava o ato de ler como um ideal a perseguir."Ix

A abordagem acadêmica da leitura vincula-se aos interesses das classes dominantes, e é derivada de uma definição específica de homem letrado, de padrões elevados e refinados, mais vinculados aos padrões estéticos dominantes. Para Donaldo Macedo, quando o ensino e o desenvolvimento da leitura funcionam como mera decodificação do código escrito, centrado na produção de leitores que respondam apenas a requisitos básicos para atender aos anseios da sociedade contemporânea, sem preocupação em transformá-la, trata-se de uma perspectiva utilitarista da leitura. A perspectiva da leitura do ponto de vista cognitivo dá destaque à construção de significados a partir da dialética do indivíduo com seu mundo objetivo. Segundo Freire, deve-se partir da palavra mundo e do mundo que se pode criar a partir dela, ao invés de apenas decodificar as palavras (FREIRE; MACEDO, 2013).

Não cabe aqui desenvolver o debate sobre a prática pedagógica, pois seria assunto para outro estudo, mas a escola enquanto espaço de sociabilidade e mediação tem centralidade na construção de sujeitos históricos críticos e atuantes. A leitura é uma, claro que não a única, 
das maneiras de construir o conhecimento em diálogo com a realidade concreta. Fica latente no debate sobre a leitura na escola que, muitas vezes, foi destituído o caráter de entretenimento da atividade, desvinculando a prática do prazer e do estímulo à imaginação.

Quando se torna a via principal e muitas vezes exclusiva de acesso à leitura, o sistema escolar destitui o lugar do livro como um guia, "um texto ao qual se pergunta a arte de viver". Segundo Bourdieu, um dos efeitos do contato médio com a literatura erudita via escola é o de destruir a experiência popular, despojando as pessoas de sua própria experiência, uma vez que elas se afastam de seus contextos e modos próprios de usar os textos, e os aproximam do que definiram que merece ser lido, ou seja, os bons livros; e do bom modo de apropriação, ou como aquele livro deve ser lido. O cidadão médio encontra-se "entre duas culturas, uma cultura originária abolida e outra erudita que se frequentou o suficiente para não poder mais falar da chuva e do bom tempo, para saber tudo o que não se deve dizer, sem ter mais nada para dizer" (BOURDIEU; CHARTIER, 2011, p. 241).

Cabe destacar que, além da escola, existem outras formas de letramento relacionadas às práticas culturais do cotidiano, contrariando a ideologia dominante acima mencionada. O conceito de letramento permite compreender os usos sociais da escrita e da leitura sob uma perspectiva mais ampla que a escolar e formal da alfabetização. Adriana Facina vem investigando como as práticas de letramento se estabelecem nos espaços populares, como as favelas cariocas. Segundo a pesquisadora,

[...] o cotidiano da favela é marcado por uma série de atividades culturais, tais como escolas de samba, grupos de hip-hop, bailes funk, quadrilhas de festa junina, grupos de dança e teatro, grafite, oficinas de fotografia, poesia etc. Nessas iniciativas encontramos diversas práticas de letramento, ou seja, é possível compreender os múltiplos sentidos atribuídos à linguagem, aos diferentes modos de ler, escrever e falar que caracterizam as histórias e trajetórias desses grupos. ${ }^{X}$

A leitura não é a atividade cultural mais praticada pelos brasileiros e brasileiras, que, em seu tempo livre, dedicam-se em primeiro lugar a ver televisão. Escutar música ou rádio vem em $2^{\circ}$ lugar, usar a internet em $3^{\circ}$, reunir-se com amigos ou família em $4^{\circ}$, assistir a filmes em $5^{\circ}$, usar o WhatsApp em $6^{\circ}$ e escrever em $7^{\circ}$ lugar. Usar Facebook, Twitter ou Instagram aparece em $8^{\circ}$ lugar. Ler ocupa a $9^{a}$ posição. ${ }^{\mathrm{XI}}$ Esse dado reforça que, em toda a segunda metade do século $\mathrm{XX}$, foi acentuando-se o lugar ocupado pelos meios de comunicação de massa na vida social, que acabam por se tornar o espaço-chave da socialização, muitas vezes mais que a família e as escolas.

Os meios de comunicação de massa desenvolveram-se no Brasil a partir dos anos 1920, primeiramente com o rádio, que ampliou sua audiência ao longo da década seguinte, com os programas de auditório, músicas variadas e a radionovela. Quanto ao cinema, nas décadas de 1930 e 1940, já havia nos Estados Unidos, por ocasião do desenvolvimento da indústria cinematográfica de Hollywood, a relação entre o livro na lista dos best-sellers e a possibilidade de este virar filme, por exemplo. No Brasil, as adaptações das obras literárias, especialmente para o cinema e a televisão, ocorreram principalmente a partir da década de 1960. E foram fundamentais para ampliar os leitores, que se interessam pelos livros após as adaptações. ${ }^{\text {XI }}$ 
Nos anos 1950, a TV desenvolve-se e a partir de então ocupa um lugar cada vez maior na vida do brasileiro. O que melhor caracteriza o advento e a consolidação da indústria cultural no Brasil é o desenvolvimento da TV, e a maioria das produções de nossa indústria cultural giram em torno dela (ORTIZ, 2006). Nos termos de Renato Ortiz, referindo-se ao livro Dos meios às mediações, de Jesús Martín-Barbero:

Numa terra de indígenas, negros, imigrantes e mestiços, governada por interesses oligárquicos, caberá aos meios de comunicação um papel preponderante de "mediador cultural", isto é, de atuação neste processo de formação nacional. Processo que não se restringe a este ou aquele país. [...] é na verdade parte de um traço mais geral de um conjunto de sociedades latino-americanas. ${ }^{\mathrm{XII}}$

Até 1960, apenas doze cidades brasileiras possuíam emissoras televisivas. No final da década de 1980, a Rede Globo já estava presente em $98 \%$ dos municípios brasileiros e com o total de sua programação transmitida em cores.

Ao analisar a cultura de massa, Jesús Martín-Barbero procura superar duas leituras predominantes: a primeira, hegemônica nas escolas de comunicação, reduz a comunicação a um problema dos meios, e se abstém de analisar outros aspectos da realidade social. A segunda relaciona a cultura de massa ao problema da degradação da cultura, que se torna um todo homogêneo envolvendo indivíduos, classes e grupos sociais. Para o autor, o massivo encontra-se ligado ao longo e lento processo de "gestação do mercado, do Estado e das culturas nacionais", e aos "dispositivos que nesse processo fizeram a memória popular tornar-se cúmplice com o imaginário de massa". Para ele, "a cultura de massa é a primeira a possibilitar a comunicação entre os diferentes estratos da sociedade [...] enquanto o livro manteve e até reforçou durante muito tempo a segregação cultural entre as classes". (MARTíN-BARBERO, 2009, p. 132).

Martín-Barbero contribuiu para os estudos de recepção, principalmente das mensagens veiculadas pelos meios de comunicação de massa, por meio de sua teoria das mediações culturais, em que a abordagem do contexto se torna fundamental para a compreensão dos múltiplos dispositivos socioculturais que envolvem a emissão e a recepção das mensagens. A recepção midiática, para Martín-Barbero, é um processo de interação em que o receptor interpreta a mensagem a partir de seu repertório sociocultural. Assim, o eixo do debate, segundo o pesquisador, deve se deslocar dos meios para as mediações, isto é, para as articulações entre práticas de comunicação e movimentos sociais, para as diferentes temporalidades e para a pluralidade de referências culturais.

Para Silviano Santiago, os críticos modernistas distinguiram a produção cultural entre o espetáculo, manifestação legítima e autêntica da cultura, e o simulacro, entretenimento da indústria cultural e a parte diabólica do sistema. O espetáculo levaria à reflexão, e o simulacro apenas serviria para matar o tempo. O grande inimigo a ser combatido por educadores e intelectuais seriam os meios de comunicação de massa, e os principais valores a serem preservados seriam os da arte e da literatura eruditas (SANTIAGO, 2004, p. 130). Entretanto, no mundo contemporâneo, abre-se a possibilidade de aprimoramento do ato da leitura, que transcende a experiência da escrita fonética e adentra o mundo das imagens e da oralidade. A expansão da mídia colocou em diálogo e em tensão práticas culturais diferenciadas. 


\section{Bibliotecas: usuários e usos}

As bibliotecas constituem um espaço importante de mediação entre os sujeitos e o mundo da leitura. O objetivo inicial da pesquisa foi realizar um estudo comparativo das práticas de leitura em duas bibliotecas, e a escolha levou em consideração a localização de ambas. Tanto a Biblioteca Parque Estadual quanto a Biblioteca Estação Leitura estão situadas na região da Central do Brasil, que aglutina diversas modalidades de transporte público na cidade, perto da Saara, dedicada ao comércio popular, local de grande circulação de trabalhadores e trabalhadoras, pessoas em situação de rua, estudantes, crianças, criadores, constituindo territorialidades. Segundo Haesbaert, além da dimensão política, a territorialidade diz respeito também às relações econômicas e culturais; ou seja, como as pessoas utilizam o espaço, se organizam a partir dele e como dão significado a ele. "Todo território é, ao mesmo tempo, e em diferentes combinações, funcional e simbólico" (HAESBAERT, 2004, p. 3).

O segundo elemento foram os usuários das bibliotecas. Ao observá-los, procuramos informar sobre as práticas de leitura das classes trabalhadoras, caso se comprovasse que a maioria dos usuários das bibliotecas fossem oriundos das classes médias e das camadas mais desfavorecidas economicamente, o que se confirmou a partir da pesquisa.

A primeira biblioteca estudada foi a Biblioteca Estação Leitura, localizada no interior da estação de metrô da Central do Brasil, que faz integração entre as linhas do metrô, o trem e um terminal de ônibus, com a circulação de mais de 100 mil trabalhadoras/es por dia somente na estação do metrô. A localização a coloca como incentivadora de uma modalidade cada vez mais comum de leitura, que ocorre no traslado entre a casa e o trabalho, cujos suportes mais frequentes são o celular, tablet, periódicos e livros. $\mathrm{Na}$ cidade do Rio de Janeiro, por exemplo, as/os trabalhadoras/es demoram em média três horas por dia no transporte público, onde se pode observar muitos usuários lendo, trocando mensagens ou jogando no celular.

Foram realizadas 68 entrevistas semiestruturadas com seus usuários da Estação. Conforme informou a Biblioteca, o número de frequentadores mulheres é maior que o de homens, e esse dado foi corroborado pelas entrevistas. Quanto à idade, identificamos uma grande diversidade; porém, a maioria está na faixa de 41 a 50 anos ou cima de 60 anos. A escolaridade dos usuários em sua maioria foi na rede pública de ensino e alcança, no mínimo, o ensino médio completo. A renda familiar de até cinco salários mínimos corresponde a 47 dos 68 entrevistados, e apenas 3 usuários afirmaram ter renda familiar acima de 10 salários mínimos. XIV

Todos os usuários entrevistados afirmaram acessar a biblioteca pelo menos uma vez por mês, e a maioria afirma não acessar outras bibliotecas. Mais de $70 \%$ dos entrevistados afirmam gostar muito de ler e indicam essa como a prática cultural que mais realizam em seu tempo livre, por iniciativa própria. Outras atividades citadas, em menor proporção, foram passear/sair; ir ao cinema; ouvir música; praticar atividades físicas; ir ao teatro; ver filme; viajar; ver TV; estar com a família; computador; dançar; praia/ piscina; namorar. A maioria dos entrevistados leem mais de 10 livros por ano e afirmaram estar lendo um livro no momento da entrevista. Os frequentadores da biblioteca preferem os livros de ficção e os romances. Trata-se de um grupo de leitores que declarou estar ampliando sua capacidade de leitura conforme vem 
frequentando regularmente a biblioteca. Os maiores influenciadores da prática, segundo as declarações, foram mãe, pai e outros familiares; a iniciativa própria; e apenas $10 \%$ da amostragem afirmaram ser a escola. Sessenta por cento dos entrevistados acessam a internet todos os dias, a maioria para pesquisa pessoal; em seguida, aparece o acesso com o fim de estabelecer contatos sociais; seguido pelo uso profissional e para o estudo.

A Estação Leitura está no trânsito, na passagem dos usuários, por isso seu espaço precisa ser compacto e os livros em sua totalidade não podem estar à mostra. A solução encontrada foram vitrines sob a curadoria das gestoras da biblioteca, todas mulheres. As entrevistas e a observação do cotidiano da Estação Leitura apontam que os maiores referenciais para os leitores e leitoras são as vitrines de livros que circundam a biblioteca e a pequena exposição montada no corredor da estação de metrô, ao lado da Estação. E as mediadoras, que são as profissionais atuantes na biblioteca, em sua maior parte da área de biblioteconomia, também influenciam as práticas leitoras, pois atuam na mediação entre os livros e a leitura. Na hora de escolher um livro, as profissionais da biblioteca ocupam um papel central, verificam a ficha de cadastro do leitor para indicar livros que dialogam com o gosto do usuário, mas também sugerem novos títulos, que contribuam para diversificar os gêneros. Ressaltam que o índice de inadimplência na devolução dos livros é muito baixo.

Durante todo o ano de 2014, Graciliano Ramos foi o escritor brasileiro mais lido entre os usuários da Estação; e Vidas secas o livro mais solicitado. Ocorre que, durante boa parte do ano, a exposição em cartaz na Galeria Estação Leitura - Arte e Literatura ${ }^{X V}$ era justamente baseada na edição comemorativa sobre os 70 anos de publicação do livro Vidas secas, com imagens do fotógrafo Evandro Teixeira (Editora Record, 2008). Nas paredes, foram reproduzidos imagens do fotógrafo e trechos do livro. As vitrines sugeriam outros livros de Graciliano e todo mês os livros eram trocados, dialogando com as temáticas relacionadas com a conjuntura ou com o calendário da cidade. Em todas as exposições, verificou-se na sequência uma grande solicitação de livros do escritor, que dialogassem com ele ou com um de seus temas. Essa relação entre a exposição e a demanda por livros continua a ser observada, sistematicamente, a cada novo projeto.

A segunda biblioteca estudada reabriu dois meses depois da Estação, em março de 2014. Trata-se da antiga Biblioteca Pública Estadual, que, após a reforma que durou mais de quatro anos e teve um investimento de 71 milhões, passou a ser denominada Biblioteca Parque Estadual (BPE). ${ }^{x V I}$ Outro fator de grande interesse, que se agrega aos acima mencionados, foi justamente a denominação Parque e a vinculação imediata com o projeto colombiano dos Parques Biblioteca; ainda que também dialogue com outros modelos, como o francês, especialmente do Centro Georges Pompidou (BPI), e as bibliotecas públicas alemãs. $A$ BPE se propôs explicitamente a ampliar suas funções e reformular sua estrutura. O prédio foi inteiramente reformado para abrigar este que seria o modelo da política estadual de investimento na marca $\mathrm{Bi}$ bliotecas Parque, especialmente voltada para áreas de conflito social.

O projeto aponta para um conceito de biblioteca que vai além de um local com uma determinada coleção de livros disponível para leitura e empréstimo. Trata-se de um centro de atividades culturais, informação e lazer, ${ }^{X V I I}$ com diversos suportes. Seu acervo conta com 3 milhões de músicas, 20 mil filmes, 200 computadores com 
internet gratuita, além de mais de 200 mil livros e documentos. Os profissionais da biblioteca são de diferentes áreas: há desde a função de mediador social, passando por bibliotecários, a arte-educadores.

Na Biblioteca Parque Estadual, foram realizadas 100 entrevistas semiestruturadas com usuários de idades diversificadas, entre 15 e 65 anos. Destes, 94\% dos entrevistados afirmou saber ler e escrever. Sobre a escolaridade, $57 \%$ estudam atualmente, apenas $2 \%$ nunca frequentaram a escola, e $71 \%$ dos entrevistados possuem o ensino médio completo; a maioria na rede pública de ensino. Sessenta e cinco por cento trabalharam e, ao serem questionados sobre a renda familiar, 36\% possuem de 1 a 3 salários mínimos de renda mensal; $20 \%$ estão entre 4 e 5 salários mínimos; e apenas $18 \%$ têm renda acima de 5 salários. XVIII

Ao serem questionados sobre a frequência, a maioria utiliza a biblioteca com regularidade. ${ }^{X I X}$ Sobre os usos, a maior parte afirma ler livros (inclusive a maioria afirma que prefere ler no papel), quadrinhos, revistas ou jornal. Mas os usos não se limitam a esse suporte: a metade usa a internet, nos computadores da biblioteca, alguns levam seu próprio computador e outros usam o celular. Os usuários também vão ver filme, descansar, passar o tempo, trabalhar ou acessar a programação paralela, tais com a exposição, o teatro, palestras e o programa educativo. Quando perguntados sobre o tipo de material que costumam ler, a maioria afirma ler jornais; em seguida, livros de literatura, revistas e textos na internet.

Contrariando a média nacional, a maior parte dos entrevistados afirmaram gostar de ler em seu tempo livre e que a leitura é um de seus passatempos favoritos; em segundo lugar, estão atividades físicas, ver filmes e séries; em seguida, atividades culturais; ver TV foi menciona- do por apenas $5 \%$ dos entrevistados. Cinquenta e sete por cento afirmam ler atualmente mais do que há um ano atrás; $19 \%$ leem com a mesma frequência; e apenas $15 \%$ leem menos. O argumento mais apresentado para não lerem com mais frequência é a falta de tempo (54\%). A maioria afirma não ter dificuldade para ler, mas os que têm alguma limitação afirmam que leem muito devagar.

A maioria afirma costumar escrever (66\%); em primeiro lugar, mensagens de texto no celular, mensagens em redes sociais, documentos acadêmicos ou da escola, e-mail, documentos de trabalho e pensamentos/reflexões. Sobre as razões que os levam a escrever, estão o estudo, a comunicação com outras pessoas, expressar-se, o trabalho e para aprender e melhorar o vocabulário.

Sobre quem influenciou a leitura, em primeiro lugar são as famílias (33\%) e em seguida iniciativa própria (30\%). A escola apareceu apenas em terceiro lugar (16\% dos entrevistados). Sobre a relação entre os produtos audiovisuais e a literatura, quase a metade afirma que um programa de televisão ou filme já os fez se interessar por um livro. Oitenta e seis por cento dos usuários entrevistados acessa a internet. Sobre o uso, são mais frequentes as redes sociais, as notícias e, em terceiro lugar, pesquisa pessoal ou curiosidades. Cinquenta e seis por cento afirmam realizar atividades na internet vinculadas com o que estão lendo.

\section{Experiências vivas: leitura de livros; leitura fragmentada horizontal e leitura do mundo}

A análise das entrevistas procurou identificar as principais características das práticas de leitura através da identificação dos suportes de leitura; dos conteúdos mais acessados; a frequência e 
o local de realização mais frequente da prática. Também se procurou apreender a maneira como as pessoas se sentem em relação ao tema, a força motivadora das práticas de leitura, impulsionada pelo contexto social. Foi levado em conta o que a leitura representa como prática coletiva, as predisposições impostas pelos contextos socioeconômicos e pelas competências leitoras. A prática da leitura ocorre por um lado de maneira vertical, imposta, enraizada, unívoca e, por outro lado, de forma horizontal, conversacional, compartilhada. Assim como o leitor faz uma operação de caça, esta pesquisa também procurou encontrar o leitor nômade, que muitas vezes se esconde no silêncio da leitura, da tela ou dos fones de ouvido, tendo como suportes um celular, um livro em papel ou digital, a internet, conteúdos audiovisuais e tantos outros, cada vez mais diversificados.

As falas revelam o caráter contraditório e complexo que envolve a prática. Luiz Fernando tem 18 anos e cursa o terceiro ano do ensino público. Ao longo da entrevista, contou-nos que estuda e trabalha. Mesmo sem nunca ter finalizado um livro, atualmente está lendo um sobre o tema da ostentação. Para ele, ler "ajuda a gente a se expressar". Identifica que precisa ler mais, embora esteja constantemente utilizando as redes sociais para se comunicar. Mesmo que afirme não gostar de ler, a leitura é vista de maneira positiva:

Estudo e trabalho. (...) Preciso ler mais. (...) Não é perda de tempo, mas também não é o que eu gosto mais de fazer. (...) Ler ajuda a gente a se expressar. (...) Uso muito Facebook e WhatsApp.

A resposta mais frequente da pergunta aberta por quais razões você lê foi: para se informar, se atualizar e adquirir mais conhecimento; em seguida, aparecem o prazer, o gosto, o inte- resse, o entretenimento, o lazer, frases como "para passar o tempo", "distração", "ocupar a mente", "curiosidade", "para viajar", "relaxar", "viver outra realidade", "válvula de escape", "fuga". Ou seja, a leitura têm duas funções principais identificadas pelos leitores: informar/cultivar e distrair/dar prazer.

Segundo Chartier (2011), as declarações concernentes ao que as pessoas dizem ler são uma referência pouco segura em relação a suas práticas reais, em razão do que o autor define como efeito de legitimidade. Quando perguntadas sobre o que leem, em geral entendem a pergunta como: o que é que eu leio que merece ser declarado? Então, muitas vezes, a resposta vem carregada não do que elas leem verdadeiramente, mas do que Ihes parece legítimo, que pode ou não estar em seu repertório. Aquilo que principalmente a escola apresentou como boa leitura e leitura correta.

Nas entrevistas, a diferença entre práticas reais e declaradas gera vários desdobramentos, desde a autopercepção do informante em relação aos seus atos de leitura, como a invisibilidade de muitas práticas, carentes de legitimidade, menos prestigiadas ou condicionadas, ou quando se referem a contextos desviantes do modelo disseminado, como a leitura de trechos, páginas da internet, redes sociais $^{\mathrm{xx}}$ ou em trânsito, durante o deslocamento. Para evitar que isso ocorra, adotamos uma metodologia de elaboração dos questionários tanto com perguntas abertas, que evitam sugestionar o leitor e dar mais liberdade a suas falas; quanto procurando captar as práticas invisibilizadas e, por último, o contraditório nos discursos e mesmo o não dito, que se deixa entrever através dos comportamentos e da observação participante.

Paula, 39 anos, frequentadora da Biblioteca Parque Estadual, é moradora 
do bairro Tanque, tem segundo grau completo cursado na rede pública de ensino, renda familiar de um salário e atualmente trabalha e faz um curso ao mesmo tempo. Afirma não gostar de ler, mas considera a prática importante para se informar:

Eu acho isso aqui muito interessante, pra quem nunca veio a uma biblioteca, é muito bom. Na biblioteca, gosto de ouvir música e escrever. (...) Leitura, desde pequena, não gosto. Mesmo eu não gostando, acho importante, até porque você está interagindo com alguma coisa, vendo novidades. Eu particularmente não sou muito fã. Não tenho paciência para ler. Leio para me informar.

Patricia, de 19 anos, em situação de rua, estudou até a oitava série e afirma que frequenta a BPE todos os dias, desde que abriu:

Gosto de fazer um monte de coisas aqui. Às vezes vejo filmes (...). Carrego meu celular, vejo a internet, Facebook, Youtube, pesquisa. Vejo mais as redes sociais, para procurar trabalho, ver documentos e para me comunicar. (...) Eu leio mais por curiosidade. Leitura é muito bom. Se faltar alguma coisa no universo, não pode ser a leitura. Tenho bastante concentração, é difícil eu me distrair. Quando estou com o livro, esqueço o mundo, esqueço a pessoa, esqueço tudo, horário. (...) Eu gosto de poesia. Quando fico triste, fico o dia todo vendo poesias, acalma o coração. Se você estiver triste, pode ler uma poesia; se quiser saber mais sobre o mundo, pode ler. Porque a gente tem que saber mais sobre o mundo. (...) A minha avó, que lia bastante e era professora, falava que biblioteca era para livro. Nunca tinha visto uma biblioteca com computador, filme, teatro, musical. Biblioteca moderna, acho bom. Se não tivesse a biblioteca, o dia seria péssimo. Porque aqui no centro não tem nada de bom.

A leitura de textos é perpassada por duas dimensões principais, que muitas vezes ocorrem simultaneamente, não necessariamente de forma harmoniosa. Há a leitura orientada, oriunda da obrigação escolar ou universitária, e/ou relacionada ao trabalho, e a leitura feita por livre escolha. A maioria das pessoas afirma ler mais por prazer do que por obrigação. Sobre as relações entre leitura condicionada e profissional ou autossugerida, obrigação e prazer na leitura, muitas vezes, especialmente na escola, verifica-se uma dicotomia onde o prazer se atrela ao dever e se anula. A leitura por prazer tende a ser mais ressaltada nas falas, enquanto a leitura condicionada e a leitura fragmentada (nas redes sociais, mensagens de texto no celular, por exemplo) não costumam ser mencionadas, a menos que se pergunte explicitamente. O fato de a maior parte dos leitores frequentes afirmarem que leem por prazer demonstra a necessidade de fortalecer a formação de leitores, baseados nesse interesse.

Valter, estudante de 26 anos, morador de Vila Isabel, cursando o ensino superior, por exemplo, separa a leitura por iniciativa própria das leituras universitárias:

Leio livros de ficção e romance, e os livros da faculdade. (...) Leio muito por iniciativa própria. Eu procuro livros que estão comentados. Não sei se você conhece uma rede social chamada Skoob. Tenho um perfil. Vejo o perfil das pessoas que leram livros parecidos com os meus. Busco me informar e ler. (...) Leio no meu tempo livre. No início do período. Durante a época de provas, nem pego o livro, pois sei que não vou conseguir ler. (...) Quando leio por iniciativa própria, escolho 
livros que me interessam. Quando leio por obrigação, vejo um índice maior de dispersão. (...) Eu gosto de ler justamente porque estou buscando um entretenimento, cultura. Você cria opinião sobre outras coisas. E você viaja para outros universos.

Muitas vezes ouvimos a resposta "não leio regularmente", e em seguida "respondo e-mails, utilizo as redes sociais e pesquiso na internet" todos os dias. Os próprios leitores tendem a achar a leitura do livro, especialmente em papel, "mais leitura". Há uma tendência a valorizar mais a leitura do livro em papel, observada de forma generalizada entre os leitores. A prática aparece agregada a um valor positivo, pois, segundo os entrevistados, quem a pratica tem mais chances num mundo dominado pelas novas tecnologias, onde o manejo da palavra escrita é uma ferramenta de exercício de poder e distinção social.

João Victor Soares da Cunha, 22 anos, morador da Tijuca e atualmente cursando o nível superior, afirma que lê para "adquirir conhecimento, às vezes me distrair, é uma forma de ver o mundo, de adquirir informação do mundo, o que é o mundo, que mundo é esse que vivo. É uma das verídicas fontes de informação. Porque não confio em tudo que leio na internet. Confio mais nos livros".

Os depoimentos registram a marca herdada do sistema escolar do que representa a boa literatura, o que se pode entrever na seguinte resposta dada à pergunta "O que é leitura": "Um recurso que faz com que a pessoa cresça culturalmente. Dependendo daquilo que ele leia, pode ser um desserviço a ele." O mesmo discurso aparece quando perguntamos qual a função principal da biblioteca: "Levar a cultura às pessoas"; "Transmitir cultura para as crianças"; "Fornecer uma leitura de alto nível para os interessados."
Bem como na seguinte resposta sobre a função da biblioteca:

O mais importante aqui tem que ser a leitura. Não o encontro, o show, é maravilhoso que se encontrem, mas não é o principal. O mote tem que ser o livro, o chamariz tem que ser o livro, a leitura. Mas tudo bem que o chamariz sejam outras coisas e que as pessoas possam migrar para o que eu acho mais importante nesse lugar, que é a leitura. Tudo bem que o caminho seja esse.

Ao mesmo tempo, na fala de outros usuários apareceu um questionamento às hierarquias que separam alta literatura e de entretenimento, como a do ex-aluno e agora professor da rede pública de ensino, de 27 anos:

Ler abre tua mente, ler te faz pensar, refletir, e junto com isso tem o entretenimento. As pessoas às vezes desprezam a cultura de entretenimento como se fosse algo menor. Eu leio Machado de Assis porque ele é bom, mas também porque ele consegue me entreter. Senão, ele seria apenas um cânone. A gente tem esse hábito de separar literatura de entretenimento de alta literatura, e a alta literatura, quando ela entretém, é ainda melhor. Além de ampliar minha visão de mundo, que é a parte subjetiva, mas por entretenimento também.

Com a análise do material coletado, identificamos os usuários das bibliotecas a partir dos múltiplos usos que fazem do espaço em três categorias. Os primeiros acessam mais os conteúdos audiovisuais, jogam na internet ou no celular e utilizam a biblioteca como lugar de encontro e ócio criativo. Os leitores multimídia, que acessam diversos conteúdos, ao mesmo tempo ou separadamente, utilizam as redes sociais, leem periódicos, principalmente 
revistas, mas pouco acessam o acervo de livros. Por fim, há os leitores assíduos, que estão iniciados na prática de leitura a partir dos livros, mas muitas vezes agregam a internet como suporte, sem perder a referência do livro em papel. Aparecem aqui os leitores habituais de literatura, que pegam livros emprestados; e/ou estudantes, que se apropriam da biblioteca para estudar com seu próprio material ou acessam os livros acadêmicos do acervo.

Alan, de 31 anos, por exemplo, com o primeiro grau completo e atualmente em situação de rua, afirma que usa a internet, vê filme, lê jornal e revista de vez em quando. Para ele, "leitura é bom para esclarecer a cabeça”. Morador do Centro, ele nos conta: "Eu venho na parte da manhã, antes do trabalho. Foi a primeira biblioteca em que entrei. Eu fico na internet, vejo filme. Eu leio jornal, revista de vez em quando." Tainá, 17 anos, está no segundo ano do ensino médio da rede pública e trabalha. Mora em Vila Isabel e frequenta a biblioteca quase todos os dias, antes do trabalho. Ao ser perguntada sobre o que faz na biblioteca, respondeu: "Leio alguns livros, alugo, mexo mais na internet e às vezes tento assistir a um filme. (...) Venho normalmente sozinha." Sobre a principal função de uma biblioteca, responde que deve ser um "lugar onde você possa encontrar educação, mas de outra forma, de outro modo". Ao mencionar as razões para ler, afirma: "Lendo, eu pego conhecimento. Mais que com o professor. Eu guardo o que leio, e ainda posso ler de novo. (...) Me distraio rápido, mas consigo ler bem. Ler é aprender de uma forma diferente."

Silmara, 15 anos, 10 ano do ensino médio da rede pública, mora em São Cristóvão. Usa mais a internet, para se comunicar através das redes sociais, mas não identifica essa prática como leitura:

Tenho internet em casa, e acesso todo dia. Mas não sou muito boa nis- so [leitura]. Fico trocando mensagem com meus amigos, familiares, namorado. Tenho um grupo do colégio na internet. Escrevo mais no computador do que à mão.

Como desdobramento de cada tipo de leitura, podemos dividi-las em profanas e profissionais. As leituras profissionais são comuns para pessoas que atuam enquanto críticos, pesquisadores, escritores e outras atividades relacionadas diretamente aos textos, e por isso estão dotadas de uma disposição estética para com o texto. Bernard Lahire (2004, p. 181), com base tanto na teoria estética de Bakhtin, quanto na sociologia da produção e consumo cultural de Pierre Bourdieu, considera que a apropriação dos textos se dá na dicotomia entre disposições estéticas e disposições éticas.

A disposição estética privilegia a forma artística em detrimento do conteúdo ou função, enquanto a disposição ética rechaça a separação entre forma/ função, forma/conteúdo, modo de representação/conteúdo representado (LAHIRE, 2004, p. 181). Os leitores profanos, que possuem uma disposição de leitura ética, ou seja, identificam-se ou rechaçam as histórias que leem, são muitas vezes considerados apenas consumidores e espectadores pela teoria do campo cultural. Especialmente quando se trata de best-seller e da chamada literatura de entretenimento. No entanto, esta é a leitura mais praticada, pois mesmo um leitor profissional pratica a leitura profana, vinculada a experiências sociais que lhe são sensíveis - ou seja, a maior parte das pessoas se identifica com histórias verdadeiras, reais, cotidianas, ou pelo menos escritas como se fossem reais ou verdadeiras (LAHIRE, 2004, p. 184). O que varia, portanto, são as experiências que as pessoas vivem. Além, é claro, das desigualdades sociais a respeito do acesso ao material impresso, bem como 
o manejo linguístico e estilístico de cada leitor, que influenciam e demarcam as escolhas de determinados textos em detrimento de outros. Igor, de 34 anos, cientista social com mestrado, traça uma relação direta entre seus autores favoritos no momento por compartilharem com ele uma disposição ética, além de ressaltar a leitura por livre escolha:

Meu investimento agora é em literatura brasileira, de gente jovem. Gente que tem mais ou menos a mesma idade, que está vivendo mais ou menos a mesma coisa. Senti muita falta disso na minha formação literária, sempre estava lendo pessoas vivendo outras coisas, em outro tempo. Quando eu descobri quem estava escrevendo sobre as coisas que eu estou vivendo, exatamente, com a minha idade, encontrando saídas pras coisas desse tempo, foi maraviIhoso. É um investimento bem recente, coisa de dois anos para cá. (...) E é maravilhoso ler pelo prazer, e não pelo trabalho, como eu fazia antigamente, quando eu tinha que fichar, produzir alguma coisa sobre.

Lahire destaca como fator de identificação menos uma correspondência entre situações escritas e vividas e mais as possibilidades que cada um tem de entrar no mundo do texto, ao mesmo tempo relacionando-se com o desconhecido, e, ao usar a imaginação, ampliando e transformando o conhecido (LAHIRE, 2004, p. 186). A visão iluminista do tipo de leitura que levaria à emancipação é aquela disciplinada e orientada por obras instrutivas ou conhecidas como de alta cultura, escolhidas pelos especialistas, incluídas no cânone. Os outros tipos de leitura eram considerados nefastos, inadequados e associados negativamente à ociosidade. Ou seja, foi uma visão de democratização autoritária, e ainda persiste em larga medida na formulação de políticas para a leitura, especialmente nas escolas.

A cada dia aumenta a penetração dos formatos digitais e dispositivos relacionados no mundo do livro e da leitura. Esse período vem sendo marcado, entre os leitores, por um grande volume fragmentado de leitura - estamos o tempo todo lendo várias coisas ao mesmo tempo. Com isso, a cognição mudou e continua mudando, constituindo transformações aceleradas na forma de ler, escrever, produzir e compartiIhar conteúdos culturais. As práticas de leitura tendem a se lateralizar, horizontalizar e bifurcar. Mas o livro não deixou de ser referência no cenário transmidiático, ele continua a ser debatido e apreciado. Ele apenas perdeu o papel de exclusividade como suporte do texto (METODOLOGIA, 2015).

Novas formas de leitura criam novas formas de cidadania; ser capaz de ler os códigos digitais pode tornar-se parte da construção da cidadania contemporânea. No mundo digital, a leitura torna-se mais coletiva (desindividualização do leitor). A internet favorece que se resgatem escritores, escritoras e livros desconhecidos. ${ }^{\mathrm{XX}}$ O modo de ler o mundo significa acesso aos bens culturais, e a biblioteca possui um papel fundamental nesse processo; por isso, as bibliotecas públicas podem ser parte importante da transformação da sociedade. Nas palavras de Rony, um dos profissionais da biblioteca:

Pra mim, a função principal da biblioteca é incentivar a leitura. Mas não a leitura do livro, a leitura cultural, do mundo, do ser humano, do seu espaço, das pessoas, do ambiente que você está. A biblioteca é um ponto de integração cultural.

A diversificação de suportes permite uma leitura mais horizontal, uma vez que o número de conteúdos e infor- 
mações disponíveis cresce de maneira exponencial, principalmente no contexto digital. No entanto, essa diversidade de informações demanda uma capacidade maior de edição dos conteúdos disponíveis. Num mesmo contexto, articulam-se as dificuldades em garantir as diferenças culturais e a autonomia dos povos; as desigualdades socioeconômicas e a inserção no mundo digital (CANCLINI, 2009). Nos termos do autor:

A educação e a formação de leitores e espectadores críticos costumam frustrar-se pela persistência das desigualdades socioeconômicas, e também porque as políticas culturais se desdobram num cenário pré-digital. Insistem em formar leitores de livros, e, à parte, espectadores de artes visuais (quase nunca de televisão), enquanto a indústria está unindo as linguagens e combinando os espaços: ela produz livros e também audiolivros, filmes para o cinema e para o sofá e o celular (CANCLINI, 2008, p. 18).

Há que se diversificar as políticas de incentivo à leitura, pois os públicos e suportes são muito diversificados. Esta fragmentação, que tanto nos assusta, nos coloca o desafio de ensinar a editar as muitas versões existentes sobre um assunto. A dispersão pode ser enriquecedora quando se consegue acessar os diferentes suportes e contrastar criticamente as diversas versões em disputa, pois "a mera abundância de informação que acumula, na navegação digital, textos e imagens, acontecimentos, opiniões e publicidade, não constrói pontes num mundo rompido" (CANCLINI, 2008, p. 19).

Às perguntas motivadoras, "por que leem?" e "para que leem?", encontramos uma indicação: as pessoas leem para construir seus projetos, para compreender melhor seus contextos e dialogar com suas experiências individuais, mas prin- cipalmente coletivas, e compartilhadas. A pedagogia crítica de Paulo Freire considera uma ação cultural para a liberdade dos sujeitos em formação, preocupada não apenas em nomear o mundo, mas em transformá-lo. Por isso, Freire aponta para os contextos sociais do qual fazem parte os educandos, que em nosso caso intitulamos leitores de mundo, de palavras, sons e imagens. A alfabetização emancipadora de Freire pressupõe a valorização da própria história dos educandos, mas também a apropriação dos códigos e culturas das esferas dominantes em que uma perspectiva sufoque a outra na formação da consciência e da subjetividade. Nessa concepção, a subjetividade não é apenas um ato individual, mas político; por isso, crítico, e aponta para uma consciência do mundo. A linguagem, expressa nos diversos suportes, pode ser uma ferramenta de acesso a um vasto universo de possibilidades de intervenção no mundo, compreendendo a realidade histórica social como um ato histórico, político e não determinista. A consciência do mundo se constitui na relação com o mundo; não é um ato apenas individual, mas econômico, cultural, político e também pedagógico.

Nesse sentido, cabe perguntar se através das bibliotecas estamos contribuindo para a formação de cidadãos, ou somente de consumidores. No mesmo sentido, as políticas de incentivo à leitura estão contribuindo para construir leitores somente de textos, ou de contextos? É no diálogo com o território que se pode potencializar esse encontro. Não são os usuários que devem apreender um modo correto de usar bibliotecas, mas as bibliotecas que devem aprender com seus entornos e contextos. Novas formas de leitura do mundo podem criar novas formas de participação. Com isso, ressalto o papel das bibliotecas públicas na transformação da sociedade, e também como espaços de construção de políticas diversas de incentivo às leituras do mundo, para transformá-lo. 


\section{Bibliografia}

BOURDIEU, Pierre; CHARTIER, Roger. A leitura: uma prática cultural. Debate entre Pierre Bourdieu e Roger Chartier. In: CHARTIER, Roger. Práticas da leitura. São Paulo: Ed. Estação Liberdade, 2011. p. 229-254.

CANCLINI, Néstor García. Diferentes, desiguais e desconectados. Rio de Janeiro: Editora UFRJ, 2009.

CANCLINI, Néstor García. Leitores, espectadores e internautas. São Paulo: lluminuras, 2008.

CHARTIER, Roger. As aventuras do livro: do leitor ao navegador. São Paulo: Unesp, 1998.

CHARTIER, Roger. Do livro à leitura. In: Práticas da leitura. São Paulo: Ed. Estação Liberdade, 2011. p. 77-105.

FAILLA, Zoara (org.). Retratos da leitura no Brasil 3. São Paulo: Imprensa Oficial do Estado de São Paulo; Instituto Pró-Livro, 2012.

FREIRE, Paulo; MACEDO, Donaldo. Alfabetização: leitura do mundo, leitura da palavra. Rio de Janeiro: Paz e Terra, 2013.

HAESBAERT, Rogério. Dos múltiplos territórios à multiterritorialidade. Porto Alegre, setembro de 2004 [conferência].

LAHIRE, Bernard. Del consumo cultural a las formas de la experiencia literaria. In: (Coord.).

Sociología de la lectura. Del consumo cultural a las formas de la experiência literária. Barcelona: $\mathrm{Bi}$ blioteca Económica Gedisa, 2004. p. 179-193.

MARQUES NETO, José Castilho. Políticas públicas de leitura - o PNLL. In: RUBIM, Albino; BARBALHO, Alexandre; CALABRE, Lia (org.). Políticas culturais no governo Dilma. Salvador: EDUFBA, 2015.

MARTÍN-BARBERO, Jesús. Dos meios às mediações. Rio de Janeiro: Editora UFRJ, 2009.

MELLO, Marisa Schincariol de. Como se faz um clássico da literatura brasileira. Análise da consagração literária de Erico Veríssimo, Graciliano Ramos, Jorge Amado e Rachel de Queiroz (19302012). Niterói: UFF, 2012 [tese de doutorado].

METODOLOGIA comum para examinar e medir o comportamento leitor. O encontro com o digital. Bogotá: CERLAC-UNESCO, 2015.
ORTIZ, Renato. A moderna tradição brasileira. Cultura brasileira e indústria cultural. São Paulo: Brasiliense, 2006.

SANTIAGO, Silviano. Intensidades discursivas. In: . O cosmopolitismo do pobre. Belo Horizonte: Editora UFMG, 2004. p. 125-133.

ZILBERMAN, Regina. A leitura no Brasil: sua história e suas instituições. [s.l.]: [s.d.]. Disponível em: $<$ http://www.unicamp.br/iel/memoria/Ensaios/regina.html>. Acesso em: 2 dez. 2011.

\author{
Recebido em 09/03/2017 \\ Aprovado em 15/03/2017
}

I Marisa S. Mello. Doutora em História pela Universidade Federal Fluminense. Pós-doutoranda PNPD/Capes do Programa de Pós-Graduação em Cultura e Territorialidades (PPCult), Universidade Federal Fluminense. Brasil. Contato: marisasmello@hotmail.com.

A bolsista de iniciação científica (Pibic/CNPq) Débora Rocha acompanhou a pesquisa desde o início e contribuiu intensamente na coleta de dados e análise dos resultados. A discente desenvolveu sua pesquisa de conclusão no âmbito do curso de produção cultural/UFF sobre os usos, práticas e percepções dos usuários da biblioteca em situação de rua (2016).

II A primeira edição concentrou-se na identificação da penetração da leitura de livros no Brasil e o acesso a eles. A segunda edição verificou em que circunstâncias se dá a prática da leitura. A terceira pesquisa procura avaliar e orientar as políticas voltadas para a melhoria dos indicadores de leitura e acesso ao livro do Brasil. A quarta edição ampliou o seu escopo de análise ao incluir uma avaliação acerca das bibliotecas (inclusive as escolares), o acesso aos livros digitais, o impacto de leituras e narrativas transmidiáticas e as práticas leitoras em diversos materiais, suportes e ambientes, o que foi um ganho em relação às edições anteriores.

III Disponível em: <http://prolivro.org.br/home/images/2016/Pesquisa_Retratos_da_Leitura_no_Brasil_-_2015.pdf>. Acesso em: 16 fev. 2017. 
IV Disponível em: <http://prolivro.org.br/home/images/2016/Pesquisa_Retratos_da_Leitura_no_Brasil_-_2015.pdf>. Acesso em: 16 fev. 2017.

V Disponível em: <http://prolivro.org.br/home/images/2016/Pesquisa_Retratos_da_Leitura_no_Brasil_-_2015.pdf>. Acesso em: 16 fev. 2017.

VI Comentário sobre a pesquisa realizado por Maria Antonieta Cunha, professora da Faculdade de Letras da Universidade Federal de Minas Gerais (UFMG), ex-secretária municipal de Cultura de Belo Horizonte e secretária executiva do Plano Nacional do Livro e Leitura (PNLL). Disponível em: <http://www.prolivro. org.br/ipl/publier4.0/dados/anexos/48.pdf>. Acesso em: 8 ago. 2011.

VII Disponível em: <http://prolivro.org.br/home/images/2016/Pesquisa_Retratos_da_Leitura_no_Brasil_-_2015.pdf>. Acesso em: $1 \overline{6}$ fev. 2017.

VIII Disponível em <http://prolivro.org.br/home/images/2016/Pesquisa_Retratos_da_Leitura_no_Brasil_-_2015.pdf>. Acesso em: 16 fev. 2017.

IX Disponível em: <http://www.unicamp.br/iel/memoria/ Ensaios/regina.html>. Acesso em: 2 mar. 2011.

X Projeto de mapeamento da produção cultural e das práticas de letramento em três favelas do Complexo do Alemão. Rio de Janeiro, 2011. Adriana vem realizando ainda pesquisas semelhantes em outras favelas cariocas desde 2008.

XI Disponível em: <http://prolivro.org.br/home/images/2016/Pesquisa_Retratos_da_Leitura_no_Brasil_-_2015.pdf>. Acesso em: 20 fev. 2017.

XII Para mais sobre a relação entre leitura e meios e adaptações literárias, ver Mello (2012).

XIII Disponível em: <http://resenhasbrasil.blogspot. com.br/2008/12/dos-meios-s-mediaes-comunicao-cultura-e.html>. Acesso em: 9 out. 2011.

XIV Considerando o salário mínimo no valor de $\mathrm{R} \$$ 720,00 (2014).

XV A Galeria Estação Leitura - Arte e Literatura constitui-se como um projeto à parte, mais voltado para arte-educação e produção cultural. Consegue verbas específicas para suas ações culturais (além das exposições, performances artísticas, oficinas com crianças e adolescentes). Há ainda algumas ações culturais organizadas pela Biblioteca: o evento "Encontro com Territórios", realizado em seis edições, que tem bate-papos com autores e jornalistas, sessões de autógrafos e alguns lançamentos de livros.

XVI Disponível em: <http://www.ebc.com.br/educacao/2014/03/biblioteca-parque-estadual-do-rio-vai- -atender-a-15-milhao-de-pessoas-por-ano>. Acesso em: 10 out. 2015.

XVII Disponível em: <http://www.cultura.rj.gov.br/ espaco/biblioteca-parque-estadual-bpe>. Acesso em: 10 out. 2015.

XVIII Oito por cento não responderam; $9 \%$ não têm renda fixa ou ganham até 1 salário mínimo.

XIX Catorze por cento responderam que frequentam todos os dias, $21 \%$ de duas a quatro vezes por semana, $16 \%$ uma vez por semana e $10 \%$ uma vez ao mês; $9 \%$ disseram estar indo pela primeira vez e $5 \%$ estavam visitando uma biblioteca pela primeira vez na vida, sendo que, entre eles, todos disseram que "com certeza pretendem voltar outras vezes e/ou passar a frequentar regularmente". Metade dos entrevistados não frequenta outras bibliotecas; entre os que frequentam, são públicas ou escolares.

XX Denominamos essa leitura de fragmentada, em oposição à leitura de livros inteiros.

XXI As redes sociais vêm criando espaços de críticas literárias e de obras derivadas. Uma das mais importantes redes sociais de leitores é a Skoob, frequentada em sua maior parte por jovens. Com as novas tecnologias, a distância entre o leitor e o autor pode ficar menor, reduzindo a demanda por intermediários (distribuidores). 